\title{
MUKHLISA BUBI (ON THE 150TH ANNIVERSARY)
}

\author{
Alta Khazievna Makhmutova, \\ 8 Bari Galeev Str., Kazan, 420008, Russian Federation, \\ alta1937@mail.ru.
}

Gulfiya Razilevna Gainullina, Kazan Federal University, 18 Kremlyovskaya Str., Kazan, 420008, Russian Federation, gulfiarasilevna@mail.ru.

Mukhlisa Buby (Bubi) was born in 1869 in Izh-Bubi village of the Sarapul District in the Vyatka province (currently, the Agryz district of Tatarstan). She received her primary education from her mother Mrs. Badrelbanat. When in 1901 a sixyear Tatar school for girls was opened, Mukhlisa Bubi became the head of the school. In 1905, Mukhlisa Bubi took an active part in the establishment of a new type of women's madrasa.

Mukhlisa Bubi moved to Troitsk where since 1913 she taught religion in a school for girls. In 1914, she could open women's madrasa 'Darryl-muallimat'. In 1915 she opened the seminary for women teachers and became its head. In 1917, she participated in the First Kurultai (Congress) of Muslims of Russia (Moscow, May 1-10, 1917) and was elected a member and judge of the Religious Board of Muslims. She became the world's first womanjudge in Islam. Since 1917, she worked in Ufa as the head of the Family Affairs Department in the

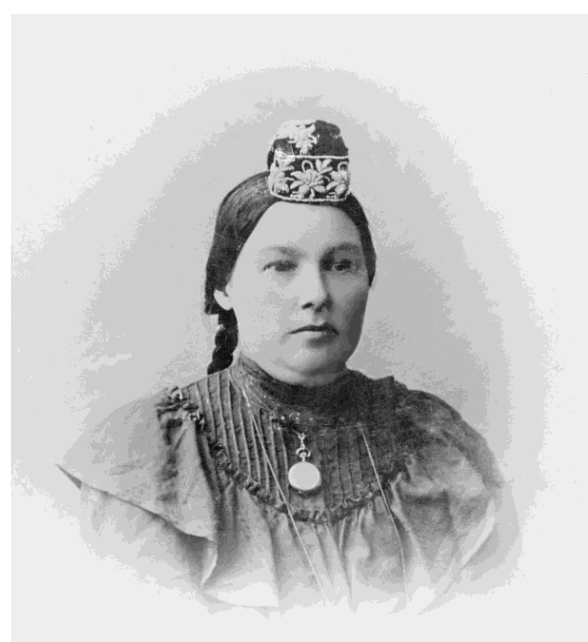

Мөхлисә Бубый (Буби) 1869 елда Вятка губернасы Сарапул өязе (хәзер Татарстанның Әгерже районы) Иж-Бубый авылында туа. Башлангыч белемне әнисе Бәдрелбәнат абыстайдан ала. 1901 елда 6 сыйныфлы татар хатын-кызлар мәктәбе ачыла, hәм Мөхлисә Бубый аның мөдире була. 1905 елда Мөхлисә Бубый яңа типтагы хатынкызлар мәдрәсәсен оештыруда актив катнаша. Мөхлисә Бубый Троицк шәһәренә күчеп китә һәм анда 1913 елдан хатын-кызлар гимназиясендә дин гыйлеме укыта. 1914 елда Дарелмөгаллимәт хатын-кызлар мәдрәсәсе, 1915 елда мөгаллимәләр семинариясе ачуга ирешә һәм аның мөдире була. 1917 елда ул Бөтенроссия мөселманнарының беренче корылтаенда (Мәскәү, 1-10 май, 1917) катнаша hәм аны Мөселманнар Диния нәзарәте әгъзасы һәм казый итеп сайлыйлар. Хатын-кызлар арасында дөньяда беренче казый була ул.
Мухлиса Буби родилась в 1869 году в д. Иж-Буби Сарапульского уезда Вятской губернии Российской империи (ныне - Агрызский район Республики Татарстан). Получила образование в медресе родной деревни, а с 1895 г. преподавала в ней. В 1901 г. создала в Иж-Бобье 6-летнюю женскую учительскую школу, где преподавание велось на татарском языке. В 1905 г. открыла медресе «ИжБобья» для женщин-мусульманок, где преподавала основы ислама, языки и литературу народов Востока. В этом медресе также преподавались педагогика, математика, география, история, физика, этика, логика, русский язык. После переезда в г. Троицк Оренбургской губернии Мухлиса Буби с 1913 г. преподавала в женской гимназии. В 1914 г. открыла женскую учительскую семинарию «Даруль-мугаллимат». Принимала участие в I Всероссийском мусульманском съезде, который проходил в Москве с 1 по 11 мая 1917 г., где была избрана одним 
Religious Board of Muslims, she also worked on filling metric books, dealing with family relations, preaching Islam and helping in other fields.

Mukhlisa Bubi was arrested in 1937 on the basis of a secret certificate stating that she was 'a member of a Bashkir counterrevolutionary bourgeois-nationalist organization'. On December 23, 1937 the sentence against Mukhlisa Bubi was executed, she was shot in Ufa. She was rehabilitated after her death.
1917 елдан Уфада эшли, Диния нәзарәтенең гаилә эшләре бүлеге белән житәкчелек итә, митрикә кенәгәләрен тутыру, гаилә мөнәсәбәтләрен жайга салу, ислам диненә дәгъватлау һ.б. эшләр белән шөгыльләнә. Мөхлисә Бубый, «Башкортстандагы контрреволюцион буржуазмилләтчел оешма әгъзасы» булуын күрсәткән яшерен белешмә нигезендә, 1937 елда кулга алына. 1937 елның 23 декабрендә Мөхлисә Бубыйга чыгарылган хөкем карары башкарыла - ул Уфа шәһәрендә атып үтерелә. Вафатыннан соң аклана. из 6 кади Центрального духовного управления мусульман, переизбиралась в 1920, 1923 и 1926 гг. Репрессирована по обвинению в участии в «контрреволюционной повстанческой националистической организации Башкирии». Арестована 20 ноября 1937 года. 23 декабря 1937 года была расстреляна. Постановлением Президиума Верховного суда Башкирской АССР от 23 мая 1960 года Мухлиса Буби была оправдана и реабилитирована.
Mukhlisa Buby (Bubi) was born in 1869 in Izh-Bubi village, the Sarapul District of the Vyatka province (currently, the Agryz district of Tatarstan). She received her primary education from her mother Mrs Badrelbanat. When in 1901 a six year Tatar school for girls was opened, Mukhlisa Bubi became the head of the school. In 1905, Mukhlisa Bubi took active part in the establishment of a new type of women's madrasa.

A famous representative of the distinguished family of educators Bubievs - Mukhlisa Abdelgallamovna Bobinskaya - Bubi was born on February 21, 1869 (new style March 5) into the family of a respected imam Abdelgallam hazrat Nigmatullovich (1834-1903) in Izh-Bubi village of the Sarapul district in the Vyatka province (currently, the Agryz district of Tatarstan). She was an educated Tatar woman with a deep knowledge of Islam and a person worthy of respect. For twenty years $(1917-1937)$, she had been a member of the Religious Board of Muslims of Russia and to this day she has remained the only female judge in the history of Islam - who knew the laws of Sharia.

The girl loved to read since her childhood. Being a student, Abdelgallam hazrat tried to found his own library and with each opportunity he complemented it with religious books and the books of Tatar and Oriental classics. Of course, little Mukhlisa read the Turkic classical works 'Legend about Yusuf', 'Kisekbash', 'Muhammadiya', 'Badavam' and knew such monajats as 'Sak-Sok' by heart. After getting acquainted with the ArabPersian languages her soul was captured by the Eastern classics. Being a teenager with a passion for knowledge, Mukhlisa was interested in the subjects her father taught at the madrasa.

Ms Bubi together with the wives of her brothers Nassima and Husnifatima initiated the estab- lishment of a new girls' madrasa, the female teachers' Seminary 'Darul-muallimat'. In 1901, it became a new six-year school for girls, which had no analogues in the Tatar world. Mukhlisa Bubi was appointed its head. Along with religious subjects various secular sciences were taught there, and since 1905 there was Russian as well. In 1907, at the expense of the Zemsky Sarapul District, a oneyear Russian-Tatar school was opened, it became a division of the Seminary 'Darul-mugallimat' [Makhmutova, 2012, p. 215-220]

In 1907, the Sarapul District Zemstvo officially recognized the work of the Bubi family in training teachers for Tatar schools: they got the right to hold examinations and to give a license 'a teacher in the Tatar school'. We should remind that earlier only the Orenburg Religious Board could officially give such rights to men. Until that time there had been no institutions issuing official certificates to women-teachers. According to the words of Gabdulla Bubi 'this school was the first in Russia to prepare women teachers' [Makhmutova, 2012, p. 220]. One of the first 'teacher' certificates was awarded to Ms Bubi and other teachers of women's madrasa. It should be emphasized that the certificate, as an official document, had to be accepted by all administrative organizations. It should also be noted that this order of the Zemstvo was available for a short time because this step was made at those times when the tsarist government organized measures to combat the Tatar national cultural movement. 'Darul-mugallimat' taught the basics of religion and secular subjects such as the TurkicTatar, Arabic, Persian, and Russian languages, geography, General history, rhetoric, mathematics, physics, zoology, and botany, in addition to moral and psychological subjects, hygiene, parenting, housekeeping, and needlework. 
Since 1908, three-month summer courses for teachers were organized in the village of IzhBobya. Graduates of these courses were also given certificates of admission to teaching. Women from different parts of Russia studied in the Izh-Bobya madrasa, especially from Kazan, Siberia, Kazakhstan, Tashkent, Przhevalsk, Bishkek, Ufa, Bugulma, Kasym, Tyumen, Astrakhan and other remote areas. Some of the girls lived in a hostel, and those who did not get a place lived in the apartments of the villagers. Not only girls, but women of all ages studied in Izh-Bobya in 19051912. Daughters came to study along with their mothers. Women with infants were also accepted for study.

After the revolution of 1905-1907, the authorities launched work to close the Jadid schools, recognized in the revolutionary years, but opened without the permission of official organizations (it is important to emphasize that sometimes teachers who opened such schools often did not have relevant papers). The government began destruction with the Center of knowledge in Izh-Bobya: the gendarme captain Budovskii came to Izh-Bobya along with hundreds of mounted guards on the night of January 30, 1911. The collapse of the center in Izh-Bobya lasted for three days. The men's madrasa was closed, all teachers, Gubaidulla and Gabdulla Bubi were arrested, they were sent to Sarapul Prison.

Thus, a tragic period began in the life of once a successful family of Bubi. Women who remained free did not fall into depression and took on all the hardships. Their mother Badrelbanat showed them an example to follow. Ms Bubi and her assistants did their best to preserve the madrasa for girls. Local authorities used various measures and threats to make the Bubi family close the madrasa for girls, butto no effect. Madrasa teachers headed by Mukhlisa Bubi did not stop the educational process. But on January 18, 1912 the Bubi school for girls was closed by order of the Director of public schools in the Vyatka province.

In 1912, Mukhlisa Bubi moved to the town of Troitsk where she, based on her experience, began to change the primary women's school, opened in 1910. At the same time, in 1913, she taught religion in a secondary school for girls. In 1914, with the sponsorship of merchants Yaushevs she could open a women's madrasa and the teachers' Seminary in 1915.

In 1917, Mukhlisa Bubi faced another challenge in her life. This was due to the changes that began in the country. At the First all-Russian Con- gress of Muslims (Moscow, May 1-10, 1917) she was elected a member of the Religious Board of Muslims and a judge. Analyzing this event the publisher and editor of the magazine "Syuyumbike" Jakub Khalili wrote the following: 'A woman was elected as one of the five judges of the religious administration. We do not know if there is another female judge in the Islamic world. In Turkey, Islamic country, we have never heard of women judges. Most likely this choice was made under the influence of the Congress of women, the voices of women. This fact proves the absence of hijab, equality of men and women in rights'. [Makhmutova, 2012, p. 238].

In the summer of 1917, Mukhlisa Bubi finished the Troitsk period of her life and moved to Ufa. Ms Bubi carried out important educational and organizational work among women under the guidance of famous religious leaders - muftis Galimdzhan Barudi (1857-1921) and Rizaeddin Fakhreddin (1859-1936). For 20 years (1917-1937), she headed the Department of Family Affairs at the Religious Board of Muslims, was engaged in the design of registers of births and dealt with family relations, preaching Islam, and seeing to other pressing issues. In 1924-1927, Ms Bubi sent her notes to the journal 'Ислам мәжәлләсе' of the Muslim administration, wrote fatwas on various religious issues and participated in the resolution of controversial family issues.

Her opinions, published ninety-five years ago, still make sense and have not lost their relevance. For example, in the article 'Women in the Islamic World', published in the first issue of the magazine, Ms Bubi assessed the role of women in the family and society, since the times of the prophet Muhammad, and noted the importance of the requirements that women were supposed to meet. 'The amount of labor, its benefits depend on the needs. There are such situations in life when any labor which might not be valued at other times and in other places could become very useful and timely. - In our area and today there is such labor, which seems to be easy and unimportant for women to shoulder, however it is very necessary and important. The fulfillment of this labor is women's duty. And there is no doubt this duty is more important even than infinite charity.' The first task is 'the preservation of our religious traditions and holidays' [Makhmutova, 2012, pp. 252-253].

In the 1920s-1930s, the persecution of the Tatar intelligentsia did not spare Mukhlisa Bubi despite her old age. She first appeared before the investigators of the NKVD on September 21, 1930. 
That day, she was brought to the interrogation according to the 59-th article of the criminal code, accused of illegal possession of gold money and valuables. All her property, gathered for the pilgrimage to Mecca, was captured but she was set free.

On November 20, 1937 Mukhlisa Bobinskaya (Bubi) was arrested. She was a talented woman and a teacher who devoted more than twenty years of her life to educational work among the Muslims of Russia and just as long she worked in the Central Administration of Muslims of Russia being an authoritative woman-judge. Mukhlisa Bubi was accused of being involved in 'counterrevolutionary rebel nationalist organizations of the Bashkortostan Republic' on November 30, 1937 at a meeting of the 'Troika' of the NKVD of the Bashkir ASSR and was sentenced to death. The 68-year-old Mukhlisa Bubi and six Muslim clerics were shot on December 23, 1937. According to the decree of the Presidium of the Supreme Court of the Republic of Bashkortostan, the family Bubi was found not guilty and was acquitted on May 23, 1960.

\section{References}

Gimazova, R. A. (2004). Prosvetitel'skaia deiatel'nost' Nigmatullinykh-Bubi (konets XIX-nachalo $X X v v)$ [The Nigmatullin-Bubis Enlightenment Activities (the late $19^{\text {th }}$-early $21^{\text {st }}$ centuries)]. 214 p. Kazan'. (In Russian)

Makhmutova, A. Kh. (2003). Lish' tebe, narod, sluzhen'ie! [You Only Shall I Serve, My People!]. 453 p. Kazan, Magarif. (In Russian)

Məkhmutova, A. Kh. (2012). Millat analary: tarikhi-dokumental' həm biografik жyyentyk [Mothers of the Nation: Historical-Documentary and Biographical Collection]. 558 p. Kazan, Жyyen. (In Tatar)

\section{МӨХЛИСӘ БУБЫЙ (150 ЕЛЛЫК ЮБИЛЕЕНА БАГЫШЛАНА)}

\author{
Альта Хажи кызы Мәхмүтова, \\ Россия, 420008, Казан ш., Бари Галеев ур., 8 нче йорт, \\ alta1937@mail.ru.

\section{Гөлфия Расил кызы Гайнуллина,} \\ Казан федераль университеты, \\ Россия, 420008, Казан ш., Кремль ур., 18 нче йорт, \\ gulfiarasilevna@mail.ru.
}

Атаклы мәгърифәтче Бубыйлар нәселенен мәшһүр әгъзасы Мөхлисә Габделгалләм кызы Бобинская-Бубый 1869 елның 21 февралендә (хәзерге стиль белән 5 мартта) дөньяга килә. Вятка губернасындагы Сарапул өязе, ИжБубый авылының (хәзер Татарстанның Әгерже районында) мәртәбәле имамы мөдәррис Нигъмәтулла улы Габделгалләм хәзрәт (18341903) гаиләсендә туып үскән татар кызы укымышлы, ислам тәгълиматын тирән белгән, зур ихтирамга лаеклы шәхес. Ул егерме ел дәвамында (1917-1937) Русия мөселманнарының диния идарәсе әгъзасы, ислам тарихында бүгенге көнгә кадәр бердәнбер булып калган казый, шәригать кануннарын яхшы белүче хөкемдар.

Сабый чактан ук Мөхлисә китап укырга ярата. Шәкерт вакытында ук үз китапханәсен булдырырга тырышкан Габделгалләм хәзрәт, жае чыккан саен, аны дини тәгълиматка караган китаплар белән дә, шәрык-татар классик әсәрләре белән дә тулыландырып торган. Әлбәттә, кечкенә Мөхлисә «Кыйссаи Йосыф», «Кисекбаш», «Мөхәммәдия», «Бәдәвам» кебек төрки классик әсәрләрне бирелеп укыган, «Сак-Сок» кебек бәетмөнәжәтләрне яттан белгән. Гарәп-фарсы телләре белән таныша башлагач, аның күңелен шәрык классикасы биләп алган. Яшүсмер чагыннан ук укуга һәвәс Мөхлисә әтисе мәдрәсәдә укыта торган фәннәр белән дә кызыксынган.

Мөхлисә абыстай бертуганнарының хатыннары Нәсимә һәм Хөснифатыйма ханымнар белән берлектә яңа төр кызлар мәдрәсәсен дарелмөгаллимәт (мөгаллимәләр хәзерләү уку йорты - укытучылар институты) оештыру эшенә алына. 1901 елга ул кызлар өчен моңа кадәр татар дөньясында булмаган яңа алты сыйныфлы уку йорты булып өлгерә һәм 
Мөхлисә абыстай аның мөдире итеп билгеләнә. Анда, дин гыйлеме белән беррәттән, төрле дөньяви фәннәр, ә 1905 елдан рус теле укытыла. 1907 елда Сарапул өязе земствосы акчасына 1 сыйныфлы рус-татар училищесы ачыла, ул дарелмөгаллимәтнең бер бүлегенә әверелә [Мәхмүтова, 2012, б. 215-220].

1907 елда Сарапул өяз земствосы бертуган Бубыйларның татар мәктәпләре өчен укытучылар хәзерләү эшен башкаруларын рәсми рәвештә таныган: аларга «татар мәктәпләрендә укытучы-мөгаллим» hәм «укытучымөгаллимә» исеменә имтихан алу һәм таныклык бирү хокукы бирелгән. Моңа кадәр мондый исемне рәсми рәвештә ирләргә бары тик Оренбург дини идарәсе генә бирүен искә алыйк. Укытучы хатын-кызларга исә бу вакытка кадәр рәсми таныклык бирүче уку йорты булмаган. Габдулла Бубый сүзләре белән әйтсәк, «Русиядә иң элек ислах кылынган вә иң элек мөгаллимәләр чыгара башлаган кызлар мәктәбе менә шушы Бубый кызлар мәктәбе» [Мәхмүтова, 2012, б. 220] була. Беренчеләрдән булып, «укытучы-мөгаллимә» таныклыгы Мөхлисә ханымга һәм кызлар мәдрәсәсенең башка мөгаллимәләренә тапшырыла. Таныклыклар, рәсми документ буларак, барлык административ оешмалар тарафыннан кабул ителергә тиеш булуын да ассызыклау кирәк. Шуны да искәртик: земствоның бу карары бик вакытлы кабул ителгән булып чыга, чөнки бу адым патша хөкүмәте татар милли-мәдәни хәрәкәтенә каршы чаралар хәзерләгән дәвергә туры килә.

Дарелмөгаллимәттә дин нигезләре, дөньяви фәннәр, ягъни төрки-татар, гарәп, фарсы, рус телләре, география, гомуми тарих, риторика, математика, физика, зоология, ботаника, моннан тыш хатын-кызлар өчен әхлак (һәм психология), гигиена, балалар тәрбиясе, йорт (хужалык) алып бару, кул эшләре кебек мөһим дәресләр дә була. 1908 нче елдан башлап, ИжБубыйда мөгаллим һәм мөгаллимәләр өчен өч айлык жәйге курслар эшләп килә. Бу курсларны тәмамлаучыларга да хөкүмәт тарафыннан рөхсәт ителгән мөгаллимлек һәм мөгаллимәлек таныклыклары тапшырыла. Иж-Бубый мәдрәсәсендә Россиянең төрле почмакларыннан, бигрәк тә Казан, Себер, Зайсан (Казахстан), Ташкент, Пржевальск, Бишкек, Уфа, Бөгелмә, Касыйм, Төмән, Әстерхан һәм башка ерак жирләрдән килеп укучы хатын-кызлар күп бул. Кызларның бер өлеше тулай торакта яшәгән, урын житмәгәннәр авыл кешеләрендә фатирда торганнар. 1905-1912 елларда ИжБубыйда кызлар гына түгел, төрле яшьтәге хатыннар да белем алган. Аналары белән бер үк вакытта кызлары да укырга килгән. Имчәк балалары белән килгән хатыннарны да укырга кабул иткәннәр.

1905-1907 еллардагы инкыйлабтан соң хакимият революция елларында танылу алган, ләкин рәсми оешмаларның рөхсәтеннән башка гына ачылган жәдид мәктәпләрен ябу эшен жәелдерә (мондый мәктәпләрне оештырып жибәргән мөгаллим-мөгаллимәләрнең үзләренең дә күп очракта яраклы документлары булмавы хакында да әйтү мөһим). Бу эшне патша хакимияте Иж-Бубый белем учагын жимерүдән башлый: 1911 елның 30 гыйнварына каршы төндә Иж-Бубыйга, йөзләгән атлы стражникны ияртеп, жандарм ротмистры Будогоский килә. Бубый мәгариф учагын тар-мар итү өч көнгә сузыла. Ирләр мәктәп-мәдрәсәләре ябыла, барлык мөгаллимнәр һәм Гобәйдулла белән Габдулла Бубыйлар кулга алына, Сарапул төрмәсенә жибәрелә.

Шулай уңышлы эшләп килгән Бубыйлар гаиләсе тормышында фажигале чор башланган. Иректә калган хатын-кызлар төшенкелеккә бирелмиләр, бар авырлыкны үз жилкәләренә алалар. Үрнәкне әниләре Бәдрелбәнат абыстай күрсәтә. Мөхлисә ханым һәм аның ярдәмчеләре, кызлар мәдрәсәсен саклап калу өчен, бар көчләрен, бар тырышлыкларын куя. Жирле хакимият, кызлар мәдрәсәсен Бубыйларның үзләреннән яптырыр өчен, төрле куркыту чаралары кулланса да, нәтижәгә ирешә алмый. Мөхлисә ханым житәкләгән мөгаллимәләр мәдрәсәдә уку-укыту процессын туктатмый. Ләкин 1912 елның 18 гыйнварында, Вятка губернасының халык мәктәпләре директоры карары белән, Бубый кызлар мәктәбе дә ябыла.

1912 елда Мөхлисә абыстай Троицк шәһәренә күчеп китә һәм анда 1910 елда ачылган башлангыч хатын-кызлар мәктәбен Бубыйлар тәжрибәсе нигезендә үзгәртергә керешә. Бер үк вакытта 1913 елдан ул кызлар гимназиясендә дин гыйлеме укыта. 1914 елда ул сәүдәгәр Яушевларның матди ярдәме белән хатын-кызлар мәдрәсәсе, 1915 елда мөгаллимәләр семинариясен ачуга ирешә.

Мөхлисә Бубыйның тормышы 1917 елда тагын бер тапкыр кискен үзгәреш ала. Бу Үзгәреш, әлбәттә, илдә башланган үзгәрешләр белән тыгыз бәйләнештә була. Бөтенроссия 
мөселманнарының беренче корылтаенда (Мәскәү, 1-10 май, 1917) ул Мөселман Диния нәзарәте әгъзасы һәм казый итеп сайлана. Бу хәлне анализлап, «Сөембикә» журналының нәшире һәм мөхәррире Якуб Хәлили түбәндәге сүзләрне язган: «Идарәи диниягә биш казыйның берсе хатыннардан сайланды. Без ислам галәмендә мөслимә казыяның барлыгын белмибез. Ислам мәмләкәте булган Төркиядә дә хатыннардан казыя барлыгын ишеткәнебез юк. Менә бу, мөслимә казыя сайланып куелу, хатыннар съезды, хатыннар тавышының тәэсире белән булган эштер. Менә бу гамәл дә үк хижапның беткәнлеген, ир белән хатынның эштә, хокукта тигезлеген күрсәткән бер факттыр» [Мәхмүтова, 2012, б. 238].

Мөхлисә Бубый, 1917 елның жәендә, гомеренең Троицк чорын тәмамлап, Уфага күченә. Мөхлисә ханым шөһрәтле дин белгечләре мөфтиләр Галимжан Баруди (18571921) hәм Ризаэддин Фәхреддин (1859-1936) житәкчелегендә хатын-кызлар арасында зур оештыру, аңлату эшләре алып бара. Ул 20 ел дәвамында (1917-1937) Диния нәзарәтенең гаилә эшләре бүлеге белән житәкчелек итә, метрика кенәгәләрен тутыру, гаилә мөнәсәбәтләрен жайга салу, ислам диненә дәгъватлау h.б. эшләр белән шөгыльләнә. 19241927 елларда Дини идарәнең «Ислам мәжәлләсе» исемле журналында Мөхлисә ханым мәкаләләр белән дә катнашкан, төрле дини мәсьәләләргә кагылышлы фәтвалар да язган, шулай ук бәхәсле гаилә мәсьәләләрен хәл иткәндә хөкемдар да булганлыгы мәгълүм.

Аның моннан туксан биш ел элек басылган мәкаләләрендәге фикерләре бүген дә үзенең актуальлеген югалтмый. Мисал өчен, журналның беренче санында ук басылган «Ислам дөньясында хатыннар» исемле мәкаләдә М.Бубый, Мөхәммәт пәйгамбәр заманыннан башлап, хатын-кызларның гаилә hәм жәмгыятьтәге ролен бәяли һәм алар алдына Y3 чоры куйган таләпләргә туктала. «Хезмәтләрнең зурлыгы вә азлыгы, файдалы булуы ихтыяжга карап йөри. Дөньяда шундый урыннар вә шундый вакытлар була - башка бер урында вә башка бер заманда санга алынмый торган бер хезмәт бик файдалы вә бик кирәкле булып чыгадыр, - дип башлана мәкаләнең бу өлеше. - Безнең шушы өлкәбездә вә шушы көннәребездә хатыннарга йөкләнә торган авыр түгел, әмма үзләре бик кирәкле вә файдалы хезмәтләр бар. Шул хезмәтләрне итү алар өстенә төшкән бер бурыч. Әмма бурычны түләү чиксез рәвештә сәдакалар өләшүгә караганда да файдалы вә саваплы булуында шөбһә юк». Беренче бурыч - «үзебезнең дини гадәтләребезне вә бәйрәмнәребезне саклау» [Мәхмүтова, 2012, б. 252-253].

XX гасырның 20-30 еллларында татар зыялыларын эзәрлекләүләр, өлкән яшьтә булуына карамастан, Мөхлисә ханымны да, читләтеп үтми. НКВД органнары тикшерүчеләре алдына ул 1930 елның 21 сентябрендә беренче мәртәбә килеп баскан. Бу көнне аны, Жинаять кодексының 59 нчы маддәсе буенча, алтын акча һәм кыйммәтле әйберләрне законсыз саклауда гаепләп, сорау алуга тарталар. Мөхлисә ханымның Мәккәгә хаж кылу ниятеннән жыеп килгән барлык мөлкәте тартып алына, үзе иректә калдырыла.

1937 елның 20 ноябрендә Мөхлисә Бобинская (Бубый) кулга алына. Егерме елдан артык гомерен Русия мөслимәләре арасында мәгърифәт таратуга багышлаган сәләтле мөгаллим, тагын шул кадәр үк гомерен Русия мөселманнарының үзәк дини идарәсендә эшкә биргән абруйлы казый Мөхлисә ханым Бубый 1937 елның 30 ноябрендә Башкортстан АССР НКВД сы «өчлеге» утырышында «Башкортстанда контрреволюцион баш күтәрүче милләтчеләр оешмасы»нда катнашуда гаепләнә һәм атарга хөкем ителә. 68 яшьлек Мөхлисә абыстай һәм тагын алты мөселман рухание 1937 елның 23 декабрендә атып үтерелә. Башкортстан АССР Югары суды президиумының 1960 ел 23 май карары белән бертуган Бубыйлар гаепсез дип табыла һәм аклана.

\section{Әдәбият}

Мәхмүтова A. X. Милләт аналары: тарихидокументаль һәм биографик жыентык. Казан: Жыен, 2012. 558 б.

Гимазова Р.А. Просветительская деятельность Нигматуллиных-Буби (конец XIX - начало XX в.). Казань, 2004. 214 с.

Махмутова А. Х. Лишь тебе, народ, служенье! Казань: Магариф, 2003. 453 с. 